\title{
Biofilms in the gravity sewer interfaces: making a friend from a foe
}

\author{
Adrian Augustyniak (D) Pawel Sikora • Bartłomiej Grygorcewicz • \\ Daneish Despot • Burga Braun · Rafał Rakoczy • Ulrich Szewzyk • \\ Matthias Barjenbruch • Dietmar Stephan
}

Received: 1 February 2021 / Accepted: 13 June 2021 / Published online: 27 June 2021

(C) The Author(s) 2021

\begin{abstract}
Sewer systems are an integral part of our modern civilization and are an imperative underground infrastructure asset that our society relies on. In Western Europe alone, $92 \%$ of the resident pollution is connected to sewer systems. This extensive coverage of sewerage systems presents an ideal habitation for microorganisms to strive. Sewers can be considered continuous flow bioreactors. They are always colonized by bacteria, either in a planktonic state traveling along the pipe with the water flow or dragged in sediment, or organized as biofilms. Many studies have been devoted to the detrimental effects of microorganisms on sewer systems made of concrete. However, their metabolic activity can also be beneficial, lead to more effective wastewater treatment, or be beneficial for concrete pipes. This aspect has not been
\end{abstract}

A. Augustyniak $(\varangle) \cdot$ P. Sikora · D. Stephan

Building Materials and Construction Chemistry,

Technische Universität Berlin, Gustav-Meyer-Allee 25,

13355 Berlin, Germany

e-mail: adrian.augustyniak@campus.tu-berlin.de

\section{A. Augustyniak · R. Rakoczy}

Department of Chemical and Process Engineering, Faculty of Chemical Technology and Engineering, West Pomeranian University of Technology, Szczecin. Al.

Piastów 42, 71-065 Szczecin, Poland

P. Sikora

Faculty of Civil and Environmental Engineering, West Pomeranian University of Technology in Szczecin. Al, Piastów 50, 70-311 Szczecin, Poland thoroughly studied to date and requires further investigation. Therefore, in this Review, we highlighted the positive and negative activity of biofilms and their participation in five proposed mass exchange points in gravity sewers. Furthermore, we systematized and reviewed state of the art regarding methods that could be potentially used to remove or engineer these biological structures to increase the sustainability of sewers and achieve a better pre-treatment of wastewater. We have also indicated research gaps that could be followed in future studies.

Keywords Biofilm $\cdot$ Biotechnology $\cdot$ Engineering · Sewer exchange points $\cdot$ Concrete

\author{
B. Grygorcewicz \\ Department of Microbiology, Immunology and \\ Laboratory Medicine, Pomeranian Medical University, \\ Powstańców Wielkopolskich Avenue 72, \\ 70-111 Szczecin, Poland \\ D. Despot · M. Barjenbruch \\ Chair of Urban Water Management, Technische \\ Universität Berlin, Gustav-Meyer-Allee 25, 13355 Berlin, \\ Germany \\ B. Braun · U. Szewzyk \\ Department of Environmental Microbiology, Technische \\ Universität Berlin, Berlin, Germany
}




\section{Introduction}

Sewer systems play a crucial for the sustainability of modern populated areas. As far as they solve many problems with hygienic wastewater disposal and its transport to wastewater treatment plants, their operation is associated with pipe deterioration to release greenhouse gases. However, microorganisms inhabiting sewer systems that can be organized in the form of biofilm may also facilitate the pre-treatment of wastewater, suppress pathogens, and inhibit the biodeterioration process. Biofilm formation in sewer systems depends on many factors and is influenced by ever-changing conditions in the gravity sewer. For that reason, most of the research so far was dedicated to the adverse effects of biofilms in sewer systems. Recently, there is more and more data of engineering of various biological structures, although none of it has been applied in the sewers to date, creating a gap in the current state of the art.

In this Review, we aimed to indicate and discuss positive and negative aspects of biofilms in sewer systems and various possibilities to attempt their engineering. Furthermore, we have also proposed a further division of exchange points regarding the position and structure of biofilms in the interfaces of gravity sewers (Table 1). The highlights of the following chapters are provided in Tables 2, 3 and 4.

\section{Biofilms in sewer systems: activity and interfaces}

Archaeological evidence proves that the first sewer systems have existed thousands of years ago. However, the usage of sewer systems resembling modern sewers has started developing in the middle of the nineteenth century (de Feo et al. 2014). Over the years, engineers and the scientific community have been actively working on improving performance in existing sewer systems and developing new material solutions. In the early twentieth-century, sewer systems were composed mainly of bricks and stoneware; however, these materials suffered from severe structural damage as time passed. The development rate of sewer systems had significantly accelerated when concrete pipes were developed and commonly used as a building material for this purpose. Since the ' $50 \mathrm{~s}$ of the twentieth century, significant enhancement has been made in this field as many new materials have been introduced. Nowadays, modern gravity sewer systems are made of polyvinyl chloride (PVC), corrugated steel (CSP), high-density polyethylene (HDPE), polypropylene (PP), fiberglass, steel-reinforced high-density polyethylene (SRHDPE), or metal pipes (Wong and Nehdi 2018). However, all of these materials are exposed to microbial activity and biofilm formation. Based on the load capacity of pipes, these systems can be classified as rigid and flexible. Flexible pipes such as PVC, PP, or HDPE are frequently used, although most older operating sewer systems are made of rigid pipes, especially concrete and reinforced concrete (Kaempfer and Berndt 1999).

The sewer system, designed to collect fresh wastewater from households and industries, is also a complex and highly diverse ecosystem. The predominating organisms colonizing this system are microorganisms, primarily bacteria, and archaea. Under certain conditions, even eukaryotic microorganisms, e.g., protozoa or fungi, may be present, and often even mammals, like rats, colonize these technical installations. The presence and metabolic activity of primarily bacteria and archaea may cause various types of unwanted side effects, including the development of malodor and biodeterioration of construction materials (Hvitved-Jacobsen et al. 2013; Lors et al. 2017; Wu et al. 2018).

To understand the metabolic possibilities for the microorganisms, it is crucial to understand and describe the sewer system as an ecosystem. The composition of wastewater may change depending on the structure of the sewer network and the connected pumping stations (e.g., households, industry, agriculture). For example, wastewater from desalination and process industries is rejected in sewer systems (Panagopoulos et al. 2019; Panagopoulos and Haralambous 2020a, 2020b). Two important abiotic factors determining the metabolic potential of a microbial community are the availability and quality of carbon sources and the availability of electron acceptors (oxygen, nitrate, sulfate) (Wei et al. 2013; Li et al. 2017). Thinking of carbon sources first, untreated wastewater is characterized by a very high diversity of organic substrates. A high proportion of the organic load comprises easily degradable compounds (high BOD5) and a complex mixture of recalcitrant substances, like pharmaceuticals and household chemicals (Łagód et al. 2010; Onesios-Barry et al. 2014). Due to the high BOD, bacteria are very active in the 
degradation of these compounds, already when these substances enter the sewer system. As a result, oxygen availability will be a limiting factor, and anaerobic processes will take over. If there is no high turbulence in the wastewater, which might introduce some oxygen into the wastewater, already a few $\mathrm{mm}$ to $\mathrm{cm}$ below the water surface, anaerobic conditions will prevail (Madsen et al. 2006; Hvitved-Jacobsen et al. 2013).

Microorganisms growing in the sewer system will grow in two different but connected ways: planktonic biomass in the wastewater or biofilm in all interfaces. Both the planktonic and the biofilm biomass are highly active but are exposed to different environmental conditions. Concerning (bio)deterioration of the materials used to construct the sewers, primarily bacteria are considered (Noeiaghaei et al. 2017; Wu et al. 2018).

A biofilm is a structure composed of microbial cells in an exopolymeric matrix. In contrast to many clinical biofilms that maintain low diversity, environmental ones often multispecies and thrive as diverse microbial communities (Burmølle et al. 2010). Besides cells, the matrix contains organic material such as extracellular deoxyribonucleic acid (DNA), enzymes, and (in the case of sewer biofilms) inorganic substances such as sand and zeolite (Łagód et al. 2010). Localized gradients of oxygen cause the natural formation of diversified habitats where various biochemical reactions occur depending on the local microenvironment. A simplified stratification in sewer biofilms is shown in Fig. 1.

The biofilm matrix creates a favorable niche for microorganisms and provides safety from antimicrobials, regulates the penetration of macromolecular and particulate structures. In the sewer system, biofilms protect from shear stress caused by water or gas flow in the pipe. Generally, biofilms may develop to withstand high shear forces, which were well summarized and studied by Möhle et al. (2007).

Biofilms are biostructures built mainly through bacteria and archaea, which have very complex and heterogeneous structures and compositions. Therefore, they may quickly adapt to changes in the environment, e.g., availability of electron acceptors (oxygen, nitrate, sulfate) or organic nutrients. These conditions are interchangeable and depending on the quantity of organic matter, aeration, temperature, and the design of sewers. While in gravity sewers, reaeration is a normal process, in pressure sewers, oxygen availability is strictly limited (Hvitved-Jacobsen et al. 2013). Furthermore, the mass transfer to and from biofilms in sewers can depend on the flow of wastewater. Its turbulence, ventilation in the system, hydraulic depth mean of the water phase in the pipe, and the velocity and shear stress at the sewer wall (Vollertsen et al. 2008; Hvitved-Jacobsen et al. 2013).

Microorganisms present in the wastewater decompose organic matter producing energy (adenosine triphosphate, ATP) in a series of redox reactions. From the metabolic perspective, among other factors, aeration has the main meaning for the effectiveness of biochemical processes occurring in sewers. The presence of oxygen as an electron acceptor allows microorganisms to degrade organic through oxidative phosphorylation producing the highest amounts of ATP. Nevertheless, critical biochemical processes can also proceed in microaerophilic, anoxic, and anaerobic conditions, although the energetic yield for cells is lower (Kracke et al. 2015). During anaerobic conditions, bacteria use other (organic and inorganic) electron acceptors, including sulfates $\left(\mathrm{SO}_{4}{ }^{-2}\right)$ that are reduced to sulfide $\left(\mathrm{H}_{2} \mathrm{~S}\right)$. As a consequence of this process, the level of $\mathrm{H}_{2} \mathrm{~S}$ increases and poses a threat, e.g., to workers delegated for sewer maintenance. This compound is also co-responsible for odor and corrosion (Vollertsen et al. 2008; Jiang et al. 2013a).

The metabolic activity of microorganisms makes the sewer network a bioreactor that (if developed favorably) can effectively execute a pre-treatment of wastewater. Such function seems crucial when wastewater contains slowly degraded substances (Jensen et al. 2016; Ungureanu et al. 2016). Many reports show that the effluent from wastewater treatment plants (WWTP) may contain pharmaceutical substances, including clofibric acid, diclofenac, carbamazepine, and antibiotics (Favier et al. 2016; Ounnar et al. 2016). These substances can be later transported to water bodies and water intake units (Batt et al. 2006). Unfortunately, the metabolic activity of microorganisms in sewer systems does not guarantee a complete degradation in the treatment processes. As described before, the microbial communities in sewer systems are very diverse, making great metabolic and degradative potential available. The efficacy of the "pre-treatment" of wastewater in the sewer system is mainly dependent on the extension of this system, and consequently, the residence time of 


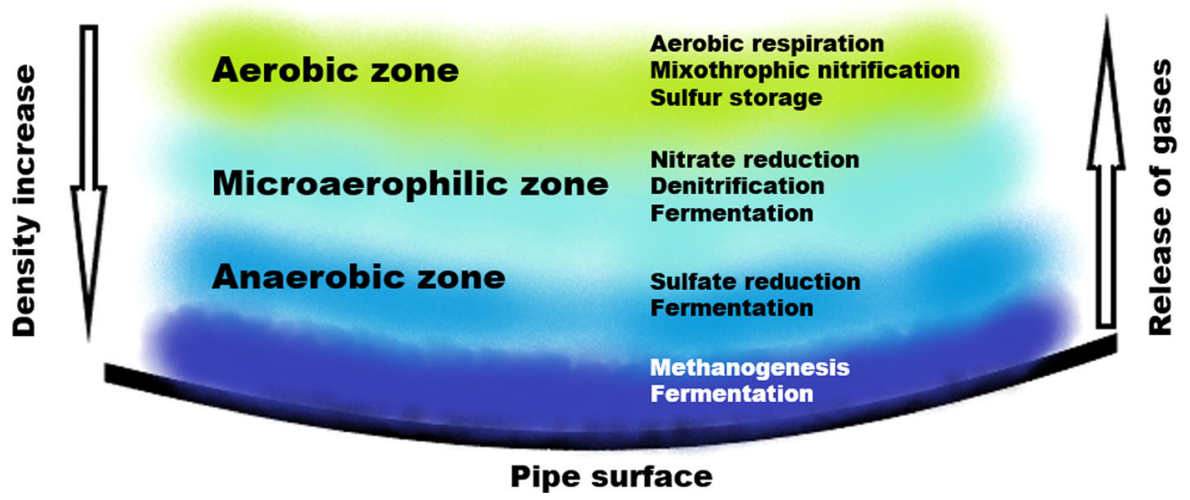

Fig. 1 Stratification of a typical sewer biofilm and main processes; modified from (Łagód et al. 2010)

the wastewater. In addition, the availability of oxygen in some cases may be a prerequisite for the degradation of certain recalcitrant compounds (HvitvedJacobsen et al. 2013; Lin et al. 2021).

In the presence of oxygen and nitrate (and to a certain amount also sulfate), many organic molecules can be degraded by one organism entirely to $\mathrm{CO}_{2}$. Under anaerobic conditions, microbial communities exchange substrates in a series of interdependent metabolic routes. Hydrolysis of complex molecules and first degradation of monomers undertaken by certain strains is later continued by other species capable of degrading simple metabolites (McInerney et al. 2008). These reactions cause the mass transfer, which is driven, e.g., by the limitation of a given substrate, electron donors (e.g., $\mathrm{H}_{2} \mathrm{~S}, \mathrm{~S}^{0}, \mathrm{~S}_{2} \mathrm{O}_{3}{ }^{-2}$ ), or changes in the environment. Among the most influential factors that regulate the succession of microorganisms on cementitious materials is a change in $\mathrm{pH}$. In concrete pipes, the $\mathrm{pH}$ on its surface is highly alkaline (reaching $\mathrm{pH}=12$ ), which has an inhibitory effect on most bacterial strains.

Nevertheless, some microorganisms such as Thiothrix, Acidithiobacillus, Thiomonas, and Halothiobacillus may adapt to the alkaline environment. All of them, except for Hallothiobacillus, can grow mixotrophically (either heterotrophically or chemolithoautotrophically) that helps them develop populations on limited resources (Okabe et al. 2007). Furthermore, chemolithotrophs from the genera Nitrosomonas and Nitrobacter were also found inhabiting concrete structures (Gaylarde and Morton 1999).

These are only several examples among many other microorganisms that are present in this environment.
Most of them are microorganisms that cannot be cultured in laboratory conditions. Even those previously cultured can shift into viable but not culturable (VBNC) states, which means that they cannot be detected in laboratory cultures (Bitton 2014). Therefore, depending on classic bacteriological methods may cause a discrepancy between studies showing different species as the cause of the corrosion, naturally considering that various strains and species may show similar activity. Therefore, from the ecological perspective, the advisable way to discern between microorganisms that contribute to the materials' deterioration should be selecting them thanks to molecular methods (e.g., sequencing, metagenomics). It can be supported with bioinformatics tools that allow estimating the metabolic potential of a given consortium with $16 \mathrm{~S}$ sequences as the input. Further, they can be their tolerance to $\mathrm{pH}$. In that case, they can be described as basophils, neutrophils, and acidophiles or groups that are tolerant to variable $\mathrm{pH}$ conditions, such as urease-producing microorganisms (LópezMoreno et al. 2014; Li et al. 2017).

The development of bacterial biofilms can be stimulated by stress factors, including oxidative stress and the limitation of nutrients and gases (Flemming et al. 2016). Such stresses are present in the relentlessly changing environment of sewer systems (Hvitved-Jacobsen et al. 2013; Lin et al. 2021). Thus, biofilm formation is unavoidable because it is supported mainly by the constant flow of wastewater continuously supplying new cells together with organic and inorganic matter (Hvitved-Jacobsen et al. 2013). Therefore, an advisable way to tackle the biofilm-associated problems, such as odors and 
corrosion, is searching for solutions that could potentially influence the biodiversity or modify the 'sewer metabolome.' In gravity sewers, there is a constant exchange of mass between biofilm, sediment, and wastewater, and thus this environment is very dynamic. It was shown by Auguet et al. (2015a), who studied changes in bacterial populations in sewer biofilm with a focus on sulfate-reducing bacteria (SRB) and methanogenic archaea (MA)—groups responsible for the accumulation of sulfide and methane. This study has shown that, similarly to the process of biogas production, higher reduction of sulfate and subsequent production of $\mathrm{H}_{2} \mathrm{~S}$ in a sewer system is limiting methanogenesis (Auguet et al. 2015a; Liu et al. 2015a; Westerholm and Schnürer 2018).

As mentioned before, cells in a biofilm will arrange themselves depending on the environmental conditions, forming layers of cells having different metabolic activity. Its density and structure limit the penetration of oxygen through the biofilm structure. Thus, anaerobic cells are likely to gather at the bottom of the biofilm. These cells are covered by others that are facultatively anaerobic and finally aerobic (Flemming et al. 2016), as shown in Fig. 1. Another interesting feature of biofilms is that cells can be attracted to this biostructure by molecular signals sent by specific microorganisms. Such a case was described on a model of Bacillus subtilis that was recruiting Pseudomonas aeruginosa to join biofilm by sending electrical or chemical signals (Lee et al. 2017; Singh et al. 2017; Humphries et al. 2017; Arnaouteli et al. 2021).

On the other hand, other pseudomonads such as $P$. protegens and $P$. putida can produce antibiotics and other inhibitory substances that prevent $B$. subtilis from sporulation and biofilm formation (Lax et al. 2019). Such interactions should be considered while determining the interspecies play between biofilm and sediment (planktonic) cells. Microorganisms have developed various systems for intracellular communication that can shape the diversity and change metabolic reactions undertaken by cells. The first form of communication among bacteria discovered was Quorum sensing, based on acylated homoserine lactones in Gram-negative bacteria and short peptides in Gram-positive (Karatan and Watnick 2009). Recently, high interest is put into electrochemical communication between cells, where microorganisms can exchange electrons directly or through redox-active compounds (Lee et al. 2017; Pankratova et al. 2018).

The complexity of microbial activity in biofilms is relatively high. In the literature, these biostructures are usually considered to be participating in one of two interphases (gas and water phase) (Madsen et al. 2006). Alternatively, these biofilms can be described by their location on surfaces that are likely to corrode., as Li et al. (2017) show. Although useful for modeling purposes, these discriminations are still simplified from the microbiological point of view because the biofilm is likely to change (or form differently) when exposed to variable conditions (Hvitved-Jacobsen et al. 2013; Liu et al. 2015a). In gravity sewers, these conditions are highly variable that makes the microorganisms inhabiting different spots of the same pipe section living in a different environment at the same time. In modeling, a certain sum of all the conditions creates output for the model, distinguishing the activity of biofilms between different exchange points. Naturally, biofilms, as a whole, create certain equilibria in the sewer. However, there is a space to study how biofilms participating in different interfaces contribute to this general metabolic activity depending on their location in the pipe (Hvitved-Jacobsen et al. 2013; Liu et al. 2015a). From the microbiological perspective, the classification of biofilm functions in the interfaces in gravitational sewers could be further developed depending on the five biofilm-containing exchange points depicted in Fig. 2.

Such distinction has not been previously reported. However, it may be that all of these exchange points based on the biofilm location may influence the specific biofilm stratification and its presence in both, water and gas phase (Madsen et al. 2006; Łagód et al. 2010; Flemming et al. 2016; Li et al. 2017). There is 


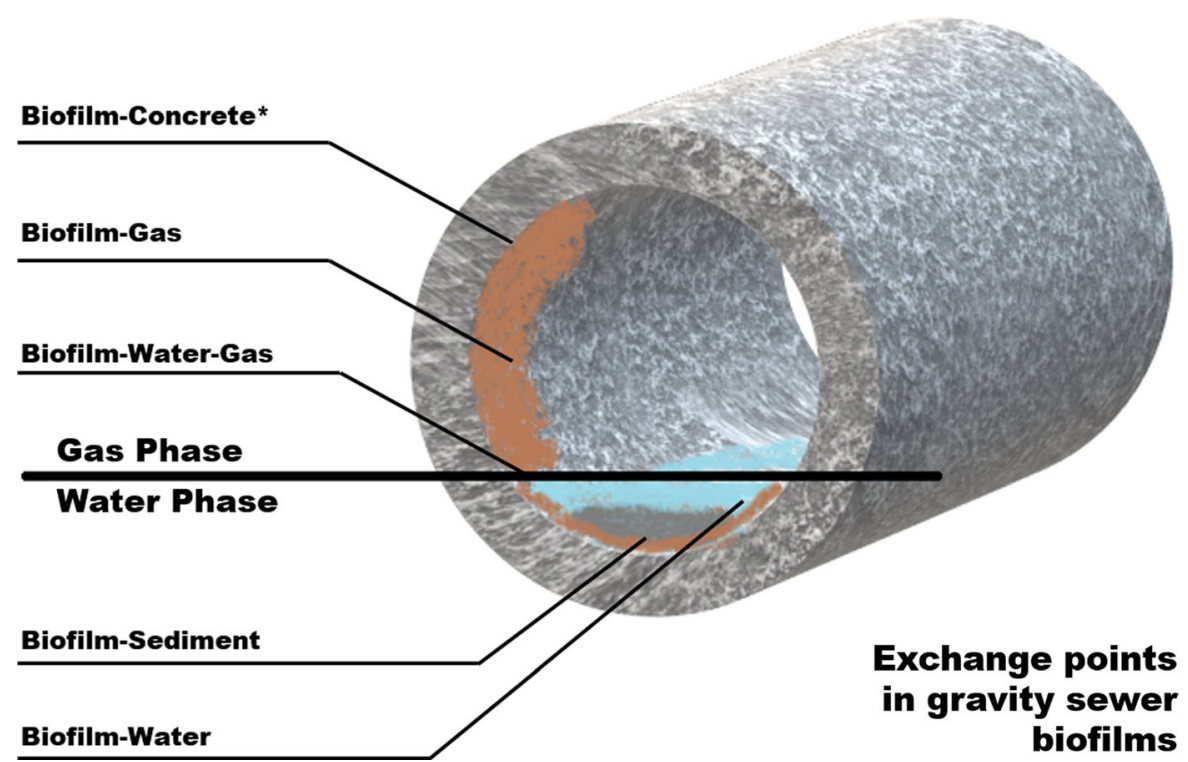

Fig. 2 Exchange points that affect biofilm formation and biofilm-derived processes in sewer systems; ${ }^{*}$ or other construction material

very scarce literature indirectly suggesting that these exchange points could be studied separately. Thus, further investigation could bring additional information on how these microbial communities are being assembled and how they contribute to the general mass transfer within the pipe. Nevertheless, some characteristic features regarding biofilm activity in the proposed exchange points are suggested in Table 1, along with references.

Table 1 Exchange points for biofilm activity in gravity sewer interfaces

\begin{tabular}{llr}
\hline $\begin{array}{l}\text { Exchange } \\
\text { point }\end{array}$ & Proposed characteristics & References \\
\hline $\begin{array}{c}\text { Biofilm- } \\
\text { Concrete }\end{array}$ & Acidification, the release of $\mathrm{H}_{2} \mathrm{~S}$ (in water phase), & Yuan et al. (2015) and Wu et al. (2018) \\
Biofilm-Air & $\begin{array}{c}\text { Conversion of } \mathrm{H}_{2} \mathrm{~S} \text { to } \mathrm{H}_{2} \mathrm{SO}_{4} \text { leading to biodeterioration } \\
\text { and } \mathrm{NH}_{4} \text { to } \mathrm{NO}_{3}\end{array}$ & Wu et al. (2018) \\
$\begin{array}{c}\text { Biofilm- } \\
\text { Water-Air }\end{array}$ & $\begin{array}{c}\text { Influence on gas fluxes. Gases (such as } \mathrm{H}_{2} \mathrm{~S} \text { ) have higher density in } \\
\text { this part the pipe }\end{array}$ & $\begin{array}{c}\text { Hvitved-Jacobsen et al. (2013), Auguet et al. } \\
\text { (2015a) and Liu et al. (2015b) }\end{array}$ \\
$\begin{array}{c}\text { Biofilm- } \\
\text { Water }\end{array}$ & $\begin{array}{c}\text { Biodegradation of compounds, including pharmaceuticals, pre- } \\
\text { treatment of wastewater }\end{array}$ & $\begin{array}{c}\text { Batt et al. (2006), Hvitved-Jacobsen et al. } \\
\text { (2013) and Ounnar et al. (2016) }\end{array}$ \\
$\begin{array}{c}\text { Biofilm- } \\
\text { Sediment }\end{array}$ & $\begin{array}{c}\text { Electrochemical communication between biofilm and planktonic } \\
\text { cells; Pre-treatment of wastewater }\end{array}$ & $\begin{array}{c}\text { Lee et al. (2017) and Pankratova et al. } \\
\text { (2018) }\end{array}$ \\
\hline
\end{tabular}

Table 2 Highlights of chapter 2

\begin{tabular}{ll}
\hline 1 & Biofilms are common microbiological structures in gravity sewers regardless of used construction materials \\
2 & Biofilms can be considered as sewer bioreactors exposed to ever-changing conditions in sewers \\
3 & We proposed five mass exchange points in which biofilms may differ in terms of metabolism and composition \\
\hline
\end{tabular}


Table 3 Highlights of chapter 3

\begin{tabular}{ll}
\hline 1 & Microbiological activity is often associated with the deterioration of sewer system \\
2 & The development of biofilms in sewer systems has hallmarks of ecological succession \\
3 & Deterioration is often accompanied by the production of malodors and greenhouse gases \\
\hline
\end{tabular}

\section{Biofilm-derived problems in sewers (microbiologically induced biodeterioration: mechanisms)}

The metabolic activity of microbial communities is often associated with the deterioration of sewer systems, depending on the materials being used. Elements are made of concrete susceptible to low $\mathrm{pH}$ when microorganisms start fermentation (Sikora and Augustyniak 2017). Biochemical processes that produce low $\mathrm{pH}$ are inevitable in sewer systems because oxygen will always be limited in wastewater and biofilms. Wastewater is carrying minerals and organic matter that is being hydrolyzed and further fermented, causing acidification of the environment, which eventually causes a drop in $\mathrm{pH}$ of cementitious materials from which the pipe is composed (Wei et al. 2013). It causes a gradual degradation of the material associated with changes in the groups of microorganisms present in the sewer environment $(\mathrm{Li}$ et al. 2017). One of the driving factors is changing $\mathrm{pH}$ over time. Initially, the $\mathrm{pH}$ of concrete pipe on the surface is in the range between 11 and 13 that initially inhibits the colonization (Yuan et al. 2015). However, the gathering of $\mathrm{H}_{2} \mathrm{~S}$ and organic material changes the conditions on the material, increasing its availability for the growth of first microbial colonizers (Shirakawa et al. 2015; Wu et al. 2018). Lowered pH allows microorganisms to start degrading organic material that leads to further acidification.

When the local environment reaches $\mathrm{pH}=9$, common acid producers become more active. At first, neutrophilic bacteria are more abundant, although they are later replaced by acidophiles that adapt to the newly created acidic environment. Among the main genera that considerably affect biodeterioration, Acidithiobacillus, Thiomonas, and Halothiobacillus $\mathrm{t}$ are referred to in most papers (Okabe et al. 2007; Harbulakova et al. 2013; Cheng et al. 2016; Lors et al. 2017). Based on the fluorescent in situ hybridization technique (FISH), Okabe et al. (2007) proposed a succession of acid producers on concrete. They have shown that the decrease in $\mathrm{pH}$ is followed by a gradual predominance of Thiothrix, Acidithiobacillus, Thiomonas, and Halothiobacillus, respectively. However, these results were based only on rRNA gene similarity without a functional identification. It should be noted that the DNA content may vary depending on the nucleolytic activity in the environment.

Bacterial metabolism can acidify the environment by numerous metabolites, including organic (e.g., acetate, butyrate, lactate) and inorganic (e.g., $\mathrm{H}_{2} \mathrm{~S}$, $\mathrm{H}_{2} \mathrm{SO}_{4}$ and $\mathrm{HNO}_{3}$ ) acids. When these substances come into contact with the surface of cementitious material, they cause the formation of ettringite, which leads to the increase in internal pressure in the material and the subsequent formation of cracks. Further acidification leads to the accumulation of gypsum $\left(\mathrm{CaSO}_{4}\right)$ formed in different hydration states that significantly weaken the composite (Okabe et al. 2007; Vupputuri et al. 2015; Augustyniak et al. 2019).

One of the main technological problems in sewers is the production of odors and noxious gases that can be harmful to humans (e.g., workers during maintenance works), and their production leads to the corrosion of sewer system (Liu et al. 2015b; Wu et al. 2018). Among other gases, hydrogen sulfide is produced mainly in the water phase, and it is further released to the gas phase. Biofilm formed on the surfaces within the gas phase contains sulfur-oxidizing bacteria (SOB) that transform $\mathrm{H}_{2} \mathrm{~S}$ to $\mathrm{H}_{2} \mathrm{SO}_{4}$, a robust corrosive agent. Apart from contributing to the formation of cracks, acidic corrosion caused by $\mathrm{H}_{2} \mathrm{SO}_{4}$ can lead to peeling of the pipe parts because of the carbonation process (Okabe et al. 2007; Shirakawa et al. 2015). The oxidation of hydrogen sulfide to sulfate is an excellent example of action caused by biofilms at two different interfaces. Sulfide arises in the biofilm present in the liquid phase, and it is transported to the interface between the liquid and gaseous state. Then it is released from water to the gaseous phase and reaches the biofilm formed in the 
upper part of the pipe. Bacteria such as Acidithiobacillus and other SOB are oxidizing the compound causing increased corrosion rate. However, it should be noted that SRB microorganisms are also present and active in the flowing wastewater. The total production of gases in developed sewer systems may contribute to global warming by releasing methane, nitrous oxide, and carbon dioxide (Jensen et al. 2016).

\section{Biofilms engineering: prospects for sewer systems}

The composition of the biofilms forming in the sewer system can be changed through different factors. Two main approaches are modifying the surface that changes the microbial activity and using external factors such as chemicals and nanoparticles that can penetrate the biofilm and mitigate the problem by lowering the viability of microorganisms (Jiang et al. 2013a; Li et al. 2018). Furthermore, recent advances in bacteriophage research have shown that wastewater carries bacteriophages showing anti-biofilm potential documented especially for monospecies biofilm (Ribeiro et al. 2018; Grygorcewicz et al. 2020b). Studies also show that bacteriophages pose reducing activity against multispecies biofilms (Lehman and Donlan 2015; Gutiérrez et al. 2015). Unfortunately, due to the complexity of environmental conditions in sewer systems and the constant co-evolution of bacteriophages and their hosts, phage application in wastewater needs further investigation (Jassim et al. 2016; Jurczak-Kurek et al. 2016; Grygorcewicz et al. 2017; Augustyniak et al. 2018; Guerrero et al. 2020). Based on current literature, five possible routes for the development of biofilm engineering techniques have been selected and are presented in Fig. 3. Each of them seems to change the diversity of arising biofilms potentially, either only one is used, or they are applied together.
The environment that can be formed in gravity sewers is generally known. However, these conditions are not constant and are subject to change, depending on the construction of the sewer system, time of the year, connection to rainwater, etc. Nevertheless, the microbial activity towards biodeterioration of pipe made of cementitious material is to proceed with already known steps. In this part, the interface between biofilm and cementitious material has a crucial role. It was confirmed that microbiota develops differently on different surface types (Lax et al. 2019). From that point of view, if the material is produced to inhibit the growth of biofilms, it might ensure higher sustainability of the whole structure. The problem with this approach is that eventually, the sediment is likely to cover the protection layer and contribute to its degradation. Another problem is that this solution could be applied only in newly built sewers or as a gradual exchange of existing parts that have to be changed. Furthermore, including antimicrobial layers or substances may also increase the risk of accumulating antibiotic (multi)resistant and biocide-tolerant bacteria (Piotrowska et al. 2020; Lin et al. 2021).

Concrete is considered the most durable and longlasting pipe material that is currently in use. In addition, it is also non-flammable and resistant to rusting, tearing, buckling, or deflection. On the other hand, the long-term durability of modern plastic materials has not yet been confirmed because these materials were developed in recent decades and still are being tested (Wong and Nehdi 2018). However, the long operating time of concrete sewer systems exposes them to biogenic corrosion. Therefore, various mitigation techniques have been proposed and tested. This research activity resulted in publications related to estimating the material's life cycle to determine the most optimal sewerage system technology (Zhao et al. 1988; Wong and Nehdi 2018). High rehabilitation costs forced three main procedures to mitigate the problem: renovation, replacement, or repair, depending on the corrosion state of the

Table 4 Highlights of chapter 4

\begin{tabular}{ll}
\hline 1 & Biofilm engineering in gravity sewers has not been investigated \\
2 & We have proposed five approaches that may be adapted for sewer systems in future studies \\
3 & Advantages, disadvantages, and knowledge gaps of the proposed approaches have been discussed \\
\hline
\end{tabular}




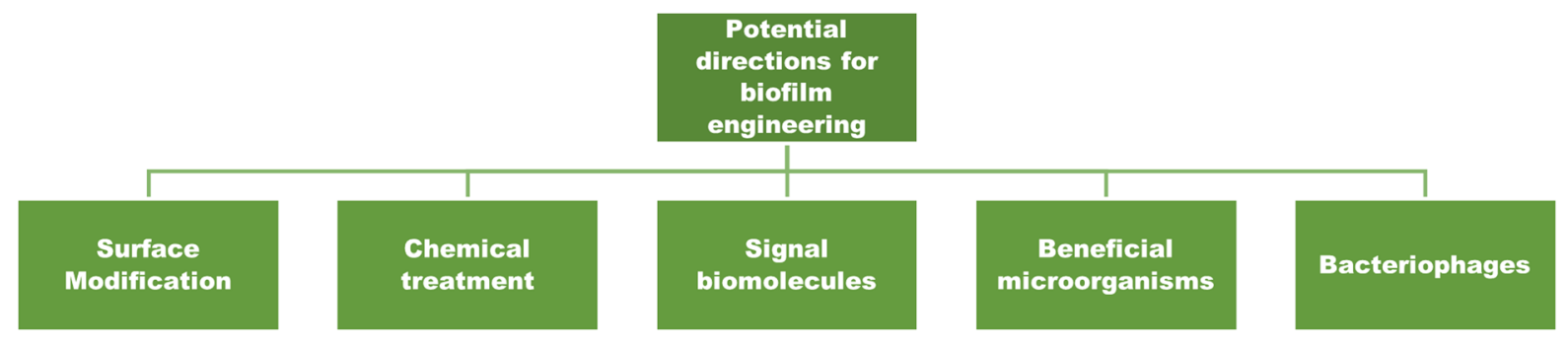

Fig. 3 Potential routes for biofilm exploration towards more sustainable sewer systems

sewerage system (Parande et al. 2006; Almeida et al. 2015). Rehabilitation techniques are summarized in works (Almeida et al. 2015; Wu et al. 2018).

Moreover, various mitigation methods were proposed, including modifying sewer tunnel environment, adjusting hydraulic parameters in sewer design, and applying material-oriented methods such as the use of protective coatings or refining the mixture design of concrete (Almeida et al. 2015). Protective coatings are designed to make a physical barrier to protect concrete from the ingress of harmful substances (mainly sulfuric acid). For this purpose, various polymer resins, including epoxy resin coating, polyurea coating, polyurethane coating, acrylic, and unsaturated polyester resin coating, were introduced ( $\mathrm{Ng}$ and Kwan 2015). Recently, Haile et al. (2010) have shown two other coatings that consisted of epoxy-containing zeolites functionalized with silver or nano-copper oxide for protection. These composites showed antibacterial activity, although the tests were conducted only on Acidithiobacillus thiooxidans. Another approach is applying polymer-modified cementitious coatings in the form of mortar ( $\mathrm{Ng}$ and Kwan 2015). These techniques can be applied to new and existing structures to isolate concrete from the surrounding environment (Haile et al. 2010; $\mathrm{Ng}$ and Kwan 2015). However, some authors suggested that the coatings may show lower abrasion resistance, and thus they require more frequent renovations ( Wu et al. 2018). The further investigation of these properties is necessary to ensure the continued functioning of protective coatings ( $\mathrm{Ng}$ and Kwan 2015; Wu et al. 2018). The effect of various coatings has recently been summarized and comprehensively reviewed (Noeiaghaei et al. 2017).

In fact, most authors discuss surface modification (or material in general) to inhibit microbial growth on the composite, including biofilm formation. Yang et al. (2018) have shown that several antibiofilm solutions were successfully tested, including highalumina cements, calcareous aggregates, and silicate admixtures. They have also shown that sulphoaluminate cement may be used to resist biodeterioration. Another interesting approach is associated with the production of highly resistant impermeable concrete elements through optimizing the mixture composition by decreasing the water-cement ratio $(w / c)$, choosing a proper aggregate type, incorporating supplementary cementitious materials (such as fly ash, metakaolin, silica fume, blast-furnace slag) or by incorporating fillers such as quartz and limestone powder ( $\mathrm{Ng}$ and Kwan 2015). In addition, polymer admixtures are highly effective in reducing the permeability of concrete. However, incorporating these materials is more expensive than conventional SCMs (Noeiaghaei et al. 2017). Another method to decrease the deterioration rate of concrete is incorporating growth inhibitors that are chemically restraining the growth of microorganisms on concrete surfaces. Studies have shown that various bactericides, including calcium formate, sodium bromide, sodium tungstate, copper phthalocyanine, zinc oxide, and titanium dioxide, can be incorporated into cement mortars. Nanomaterials were also proposed to be used as admixtures for cementitious composites. Such nanomaterials should (theoretically) grant self-cleaning properties to the material (Silvestre et al. 2016). However, there are several problems associated with this idea. First, nanomaterials tend to agglomerate, and providing even dispersion without stabilizers can be difficult even in water solution, not to mention cement mortar (Sikora et al. 2018).

Moreover, the problem with antibacterial coatings and components also lies in the fact that this activity is observable until the first layer of organic matter. Afterwards, their effectiveness drops radically, and the 
microbial population can develop on the material. However, this field is still developing, and more research is required to evaluate the compatibility of bactericides with concrete components, e.g., in the scope of their long-term performance in concrete structures (Kong et al. 2017; Noeiaghaei et al. 2017).

Chemical treatment is usually carried out to inhibit microbial overgrowth and mitigate the problem associated with the release of harmful gases such as hydrogen sulfide $\left(\mathrm{H}_{2} \mathrm{~S}\right)$ and, in turn, biogenic acid corrosion in sewer pipes. Several methods mitigate this problem via chemical treatment in the liquid phase or chemical treatment of sewer headspace. Liquid phase treatment is mainly applied to reduce and control sulfide build-up in pressure sewers, limiting $\mathrm{H}_{2} \mathrm{~S}$ being released to the sewer atmosphere when discharged in transfer points or connecting interceptors. Gravity sewers that are poorly ventilated are susceptible to limited reaeration (dissolved oxygen concentration $<1 \mathrm{mg} \mathrm{L}^{-1}$ in the bulk phase) and are dominated by anaerobic conditions requiring chemical treatment. To address sulfide occurrence in anaerobic gravity sewers, liquid-phase treatment targeting the biofilm—bulk phase interactions are applied by using chemicals that inhibit sulfate-reducing bacteria (SRB) activity. The administration of chemical agents such as free nitrous acid (FNA), $\mathrm{pH}$ shock, and iron salts are examples used to target SRB activity at the biofilmbulk interface in gravity sewers (Jiang et al. 2013a; Gutierrez et al. 2014; Kiilerich et al. 2019; Despot et al. 2021). FNA addition was shown to deactivate sewer biofilm activity when exposed for 6-24 h (Jiang et al. 2011). This same study showed that the viable microbial cells in the biofilm decreased from approximately $80 \%$ (before FNA treatment) to $5-15 \%$ after the biofilm was exposed to FNA at $0.2-0.3 \mathrm{mg} \mathrm{HNO} 2^{-}$ $\mathrm{N} \mathrm{L}^{-1}$. Nevertheless, the penetration of FNA through the deeper zones of sediment (and biofilm) diminishes the inhibitory effect (Liu et al. 2015b). For that reason, FNA was tested with other factors increasing its antimicrobial activity. Cao et al. (2019), demonstrated that the different ferric (an iron salt) dosing strategies had different impacts on SRB activity using a laboratory-scaled gravity sewer reactor. This study revealed that a high-dosage, low-frequency dosing strategy inhibited SRB activity (indicated by a $56 \%$ decrease in sulfate reduction) and is only feasible in gravity sewers with thin sediment layers (depth $<20$ $\mathrm{mm}$ ) (Cao et al. 2019). A more cost-effective sulfide control can be achieved with a low-dosage, highfrequency dosing strategy. Although iron salts demonstrate an inhibitory effect on microorganisms and effectively reduce sulfide levels in sewage ( $>90 \%)$, some studies associated the gathering of iron rust in sewers with corrosion and crack formation. The conceptual model including this phenomenon has been proposed by Jiang et al. (2014) (Fig. 4). Nitrate salts is another chemical that is typically applied to sulfide-affected sewers to control sulfide build-up by anoxic sulfide oxidation. In addition, the anoxic conditions induced by adding nitrate salts stimulate a competitive environment for sulfate-reducing bacteria (SRB) for organic electron donors (Jiang et al. 2013b; Auguet et al. 2015b). However, as complex carbon, nitrogen, and sulfur cycles simultaneously occur when nitrate is dosed into sewers, considerations in minimizing carbon source loss due to the denitrification process and reducing the potential of nitrous oxide formation and release must be made (Jiang et al. 2013b; Liu et al. 2015b).

Interestingly, even though iron compounds can diminish microbial activity, the higher iron concentrations may increase the stability of biofilm structure which was confirmed by Möhle et al. (2007). However, in this case, the effect may be indirect and depend on the oxidative stress caused by iron aggregates rather than a direct activity with cell structures suggested after studies on the Campylobacter jejuni model (Suzzi et al. 2018). A similar effect was also found for other divalent metals such as calcium and magnesium. Calcium ions were proved to affect the secretion of eDNA. The concentration of this nucleic acid is relevant for the ability of cells to form a biofilm because it mediates cell aggregation and has a meaning in their self-organization in the biofilm structure. However, the function of eDNA may differ depending on the species that secrete it (Gloag et al. 2013; Das et al. 2014). In studies on Pseudomonas fluorescens, a ubiquitous environmental bacterium, Song, and Leff (2006) have shown that the presence of magnesium ions positively influenced the transition from planktonic to biofilm cells. As for the chemical treatment of the unsubmerged sewer biofilms exposed to the sewer atmosphere, the deactivation of the sulfide oxidizing bacteria activity is affected by increasing the $\mathrm{pH}$ of the exposed concrete surface by using magnesium hydroxide or spraying biocides onto the exposed surface. For example, spraying nitrite onto concrete 


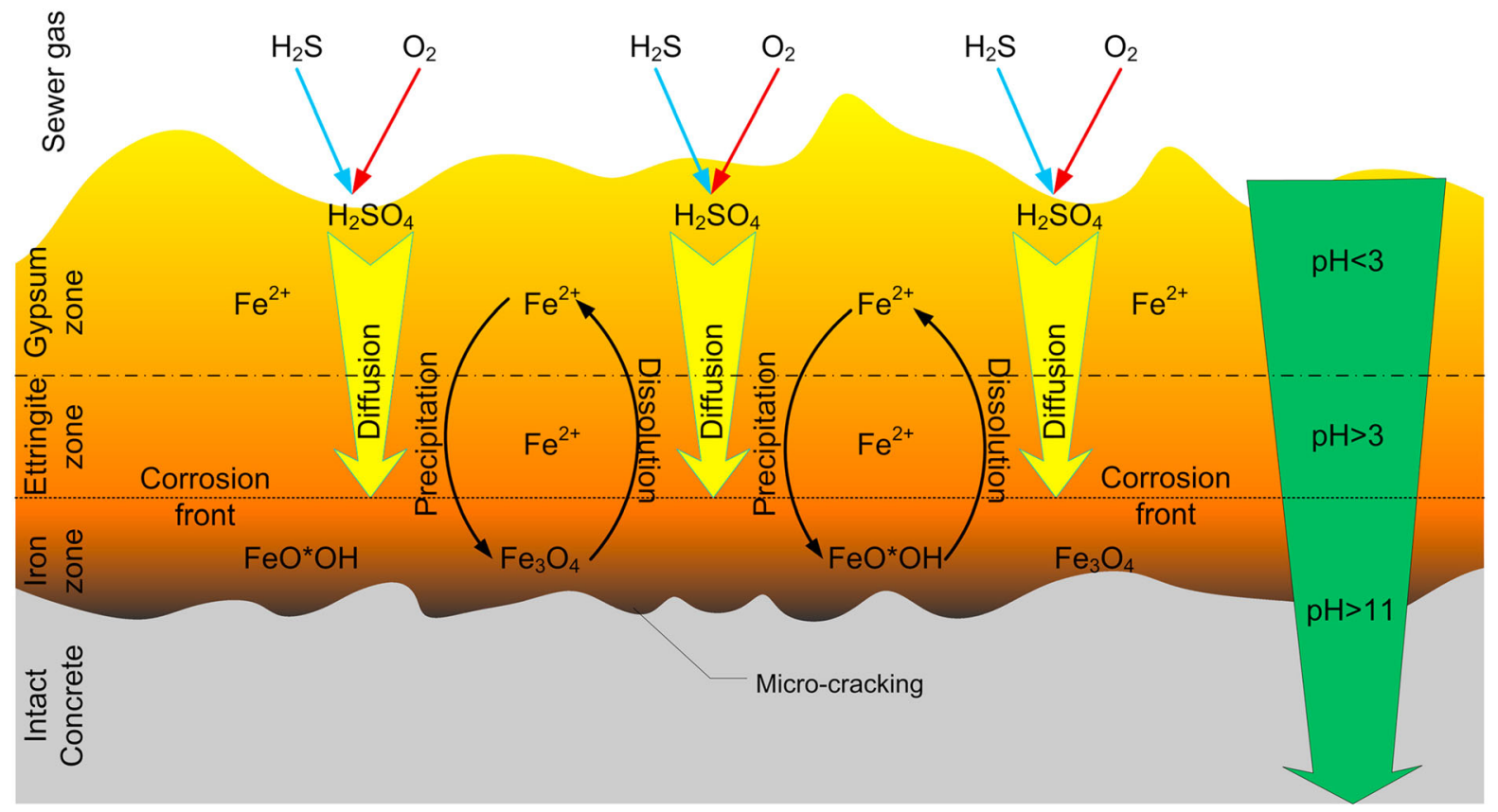

Fig. 4 Sulfide-induced corrosion of concrete in sewers by Jiang et al. (2014); reprinted with consent by Elsevier

surfaces yielding acidic conditions would lead to the formation of the free nitrous acid is known to have strong biocidal effects and deactivates SOB activity (Sydney et al. 1996; Sun et al. 2015). Using a laboratory-scale corrosion chamber, Sun et al. (2015) showed that the sulfide consumption rate of concrete coupons with active biogenic corrosion activity was reduced by approximately $80-90 \%$ when treated with FNA, highlighting the opportunity to apply a simple treatment method to protect the unsubmerged areas of gravity sewers against $\mathrm{H}_{2} \mathrm{~S}$ induced corrosion.

Bacteria and products of their metabolism are the main component of biofilms in sewer systems. While the biofilm activity is commonly regarded as harmful, some microorganisms can (at least hypothetically) contribute to the sustainability of the sewer system. As shown above, sewer systems are, in fact, bioreactors. The constant flow of wastewater brings new cells together with organic and inorganic matter, e.g., peptides and urea, which can be further included in metabolic reactions. Proteolysis and the formation of sulphide and nitrates lead to the acidification of the environment that has a detrimental effect on the pipe (Wu et al. 2018; Voegel et al. 2019; Fischer et al. 2019).
On the other hand, hydrolysis of peptides and urease activity on urea can generate ammonium ions which locally increase $\mathrm{pH}$. It appears that these phenomena can affect not only the acidification of the environment but also methane production (Kushkevych et al. 2017; Fischer et al. 2019). Ureaseproducing strains have been successfully used for biocementation and crack healing purposes in cementitious materials (Van Tittelboom et al. 2010; Abo-ElEnein, 2013). Is it possible to create a protective functional microbiological layer that would improve the sustainability of concrete and the biofilm activity towards better degradation of organic matter? Such an objective may be far-flung, and much more research must be conducted to verify this hypothesis. The literature on this topic is scarce, although there are examples of successful propagation of beneficial biofilm. Sarjit et al. (2015) have reviewed the literature indicating that certain surface modifications may stimulate beneficial (functional) biofilms.

However, in a sewer network, such application can have certain limitations. First, the microorganisms should be resistant to the high $\mathrm{pH}$ of the concrete surface. Secondly, they should remain active when other colonizers reach the surface. Therefore, a prototrophic bacterium could be an option in this 
case. Usually, bacteria from the genus Bacillus are used for this purpose. However, using them to protect sewer systems may be problematic. They are prototrophic and resistant to a harsh environment; however, the problem is that gaseous conditions in sewers can easily change to anaerobic or anoxic (Madsen et al. 2006). Bacillus spp. are aerobic bacteria, and thus they might survive in the form of spores, but they could not multiply in anaerobic conditions. For that reason, the representatives of Sporosarcina genus could be a more favorable option. These microorganisms are facultative aerobes, and therefore they are less susceptible to changes in the oxygen rate. Similarly to Bacillus spp., Sporosarcina spp. can sporulate which means that they are better adapted to difficult conditions than, e.g., Gram-negative bacteria (Logan and Vos 2015; 2015).

Another problem may lay in the efficient propagation of functional biofilms of the surface. The biofilm layer should be uniform to be achieved by spraying cells on the surface or printing the biofilm. Many articles were published on 3D printing of different materials in recent years, from polymers, through cementitious materials, up to tissues (Bose et al. 2013; Wang et al. 2017; Ngo et al. 2018). Recently, several manuscripts were published on 3D printing with the use of microorganisms as the bio-ink. The authors succeeded in printing layers of engineered $E$. coli on microbiological media, using an inexpensive printer of their design (Schmieden et al. 2018).

Interestingly, not only reference bacteria such as E. coli were used for such applications. Huang et al. (2019) successfully printed genetically engineered Bacillus subtilis that remained viable. To keep the cells active (at least for a time required to obtain a given goal), the environment should provide favorable conditions. To some extent, the material's surface could be modified to allow the biofilm to develop, or the bio-ink could contain "encapsulated living materials." Furthermore, the properties that could enable microorganisms to settle and form biofilms should be aimed at creating attachment points or increasing the surface's wettability (Sarjit et al. 2015). Such a combination of chemical signals with properly selected (or engineered) microorganisms could be used to create "programmable living functional materials," as shown in Fig. 5, even on building materials (Balasubramanian et al. 2019; Huang et al. 2019).
On cement-based materials, the main obstacle in establishing a viable biofilm is the initial $\mathrm{pH}$ which value on the surface is around 12 (Okabe et al. 2007). The propagation of biofilms on the surface has a significant advantage over the approach based on the chemical treatment of the existing biostructure. The problem with antibiotics and other antimicrobials often lies in the fact that these agents cannot efficiently penetrate EPS (Jiang and Yuan 2013; Flemming et al. 2016; Keren-Paz et al. 2018). Therefore, if the material were pre-treated with the biofilm expressing desired properties, this problem would no longer exist (or would be heavily reduced).

Bacteria can also be beneficial in other ways than producing urease. They can show antagonistic activity against pathogens and contribute to the degradation of pollutants. The effective degradation of pharmaceutical compounds or other contamination is dependent on the composition of microorganisms available in the environment. Microorganisms exist in biofilms in syntrophic, competitive, or antagonistic relations (Flemming et al. 2016). Therefore, the correct composition of the used strains (or rather metabolic activity) is essential for the pre-treatment of wastewater before it reaches WWTP. The interesting concepts that can affect the pre-treatment rate are the use of peptides, bioparticles, or even nanomaterials. The approach can be directed at least in two ways. First is using bacteriocins (antibacterial peptides) to more or less specifically reduce the number of selected unwanted microorganisms (Montesinos 2007; Mccaughey et al. 2016). The second choice could be using substances that can redirect metabolic routes to reduce the production of undesirable metabolites (Shimizu 2013). It has been shown that different nutrient inputs can redirect microbial metabolism, causing changes in the succession of acidophilic and sulfate-reducing bacteria (Zhang et al. 2017). This phenomenon could be potentially used to change the metabolic profile of biofilms and cause its reduction (or transformation), decreasing the production of toxic gases such as the abovementioned $\mathrm{H}_{2} \mathrm{~S}$ or $\mathrm{CH}_{4}$. Huge hopes are put in these methods in medicine, veterinary, or the food industry (Murima et al. 2014). Changes in the environment caused by the accessibility of nutrients or compounds can change bacteria's growth characteristics (Shimizu 2013). For example, a correlation exists between the medium and surface topology of biofilms formed by Bacillus subtilis. The 


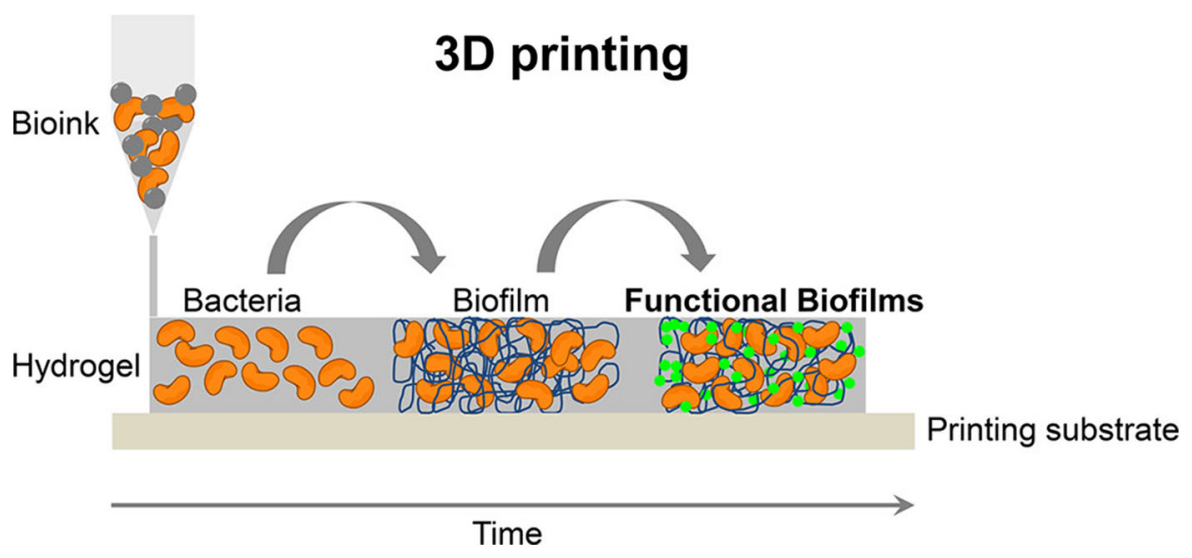

Fig. 5 Concept of programmable biofilm production and 3D printing of functional biofilms (Balasubramanian et al. 2019); reprinted with consent by ACS Publications

change observed in Werb et al.'s work (2017) was also associated with changes in observed hydrophobicity of the surface. However, the other outcome of applying indicated modulators (peptides, nanomaterials) can stimulate metabolism. For example, nanomaterials may work as stimulants for microbial metabolic activity, which was suggested on Shewanella and Streptomyces models (Maurer-Jones et al. 2013; Augustyniak et al. 2016). Lemire et al. (2017) have shown that oxidative stress (that is also caused by nanomaterials) can lead to an increase in bacterial metabolic activity. If biofilms and sediments in sewer systems could be treated similarly, the outcome could be positive for the effective pre-treatment of wastewater before it is processed in WWTP.

The key to effective engineering of biofilms may lay in altering the communication between microbial cells. Bacteria can communicate via several pathways, including signal molecules, as well as electrochemical signaling. It has been proven that intracellular communication via quorum sensing (QS) is crucial for bacteria forming and maintaining biofilms. Through QS, bacteria can determine their density in the biofilm that regulates their release from the matrix or competitive interaction resulting in the death of part of the population (De Kievit 2009; Cárcamo-Oyarce et al. 2015). Although efficient in altering the behavior of bacterial cells, QS signals are usually restricted to Gram-positive or Gram-negative microorganisms and may not be effective between these groups. It is caused by the different nature of signals that are released in the communication process. Gram-negative bacteria communicate through $\mathrm{N}$-acylohomoserine lactones
(AHL), while Gram-positive are releasing short signal peptides (Monnet and Gardan 2015; Papenfort and Bassler 2016). The use of these molecules to regulate biofilms has been proposed by multiple authors (Karatan and Watnick 2009; Saeidi et al. 2011; Worthington et al. 2012). However, treating biofilms with these signals may not be enough because of the above-shown limitation (Ren et al. 2018). Even antibiotics can be considered signaling molecules, although their use in biofilm engineering is highly unlikely because of the high risk of spreading antibiotic resistance (Romero et al. 2011; WHO 2014). In recent years, another form of communication is being increasingly described: communication based on electrochemical signals. So far, three routes of such signaling were discovered-electron transport through cytochromes and nanowires, soluble redoxactive molecules (e.g., pyocyanin), and ion-channel mediated electrical signaling (Lee et al. 2017). The most important feature of these systems is the possibility of intraspecies communication that may affect biofilm formation (Lee et al. 2017; Pankratova et al. 2018). It has been proven that signaling mediated by potassium ion channels in the biofilms of Bacillus subtilis can attract planktonic cells of $P$. aeruginosa to join the biofilm structure (Humphries et al. 2017). Understanding these interactions could be possibly used in future to engineer biofilms by external creation of such signals. Nevertheless, the application of biomolecule-based solutions in multispecies systems (such as sewer biofilms) will require the introduction of methods used in systems biology to predict possible outcome of such treatment (Nielsen 2017). 
The biodiversity in the sewer system is dynamic. Apart from altering metabolic activity by biomolecules and nanomaterials and moderation in environmental factors, microorganisms (mainly bacteria) can be subjected to their natural enemies and parasitesbacteriophages. Bacteria and bacteriophages are in equilibrium that allows them to co-exist in the environment (Salmond and Fineran 2015). Thus, there is a question of whether the bacteriophages could be used to limit the growth of problematic bacteria? Bacteriophages were active even in dense and heterogeneous environments such as slurry (Grygorcewicz et al. 2017). It proves that certain microorganisms can be reduced even in material that contains thousands of bacterial species, soil particles, and organic and inorganic matter. However, such an approach also has limitations, especially on well-developed biofilms, and because of the impermeability of biofilm structure (Flemming et al. 2016). The genome of lytic bacteriophages can contain sequences of encoding enzymes (depolymerases) that allow them to penetrate the biofilm (Hughes et al. 1998; Parasion et al. 2014; Grygorcewicz et al. 2020a). Unfortunately, not every phage can be used to efficiently reduce target bacteria because these viruses can have different life cycles with two predominant, i.e., lysogenic and lytic cycle. In the first one, the phage can mount itself in DNA and remain dormant until induced.

On the other hand, lytic phages enter the cell, multiply using the cell's replication machinery, and perform lysis. With the use of the latter group, certain bacteria could be specifically reduced. Hypothetically, the purpose of such reduction could be breaking metabolic chains through the elimination of taxa responsible for a reaction. Other applications could be associated with bacteriophages for the eradication of antibiotic-resistant pathogens and water-contaminating microorganisms (Amin et al. 2014; Mattila et al. 2015; Augustyniak et al. 2018). Eventually, these viruses could specifically reduce the number (or change the populations) of acid-producing bacteria leading to higher sustainability of cementitious composite. Unfortunately, antagonistic co-evolution between bacteria and phages plays a vital role in driving and maintaining microbial diversity at all levels of biological organization. Due to that, bacteria can develop resistance to used phages, and next phages could evolve to infect phage-resistant strains (Meaden and Koskella 2013; Scanlan 2017; De Sordi et al. 2019).

\section{Conclusions}

Biofilms are complex structures that can adapt to the environment of sewer systems and participate in several interfaces that can have different functions. Their presence can be damaging because it leads to the deterioration of building materials used for the construction. The properties of biofilms in sewer systems have a considerable impact not only on the operation of these installations but also on the health and safety of workers who do its maintenance. On the other hand, gravitational sewers can act as specific bioreactors providing wastewater treatment before it flows into WWTP. In this Review, we have shown the significant and unexplored potential of altering biofilms in our favor, i.e., towards better sustainability of sewers and/ or the quality of wastewater that reaches WWTP. Furthermore, we have indicated that successful biofilm engineering needs to be preceded with an indepth analysis of biofilm regarding all mass exchange points and not only studies of water or air phases. Here, we suggested the division of these exchange points into five areas. We hope that this will be a starting point for further scientific discussion.

From the current state of the art, engineering biofilms seems to be a demanding and far-flung objective. Here we have shown that some goals may be achieved with biotechnological methods that alter bacterial physiology or modulate their abundance with bacteriophages. Nevertheless, novel solutions must be effective and inexpensive so that they can be commonly applied. From this perspective, the use of proteins or agents produced through genetic engineering may be too costly to be commonly applied. On the other hand, some methods can be both effective and inexpensive, such as the production of biomass (for functional biofilms) and phages. However, to efficiently modify biofilms occurring in sewer systems, a combination of all indicated chemical and environmental factors might be necessary. Future works should be directed into gathering data showing how proposed methods may affect biofilms in pilot plants resembling gravity sewers or real-life conditions. Moreover, the importance of mass exchange points cannot be omitted because biofilms can have a 
different role in each of them. Therefore, it is necessary to collect data from various spots in the pipe so that the engineered biofilm could be better adapted to play its role.

It will be possible if the biofilm is appropriately applied to the surface, which could be achieved via 3D printing. Such technology was introduced to many fields, including medicine, design, and building construction. Can we 3D print long-lasting beneficial biofilms on sewer system components or even building materials in general? Before this question can be answered, there is much research to be done beforehand.

Acknowledgements This manuscript was supported by the National Science Center, Poland (PRELUDIUM Project No. 2018/31/N/NZ1/03064, granted to Adrian Augustyniak. Authors from Technische Universitaet Berlin were also supported by the German Research Foundation (DFG) as part of the Research Training Group on Urban Water Interfaces (GRK 2032).

Funding Open Access funding enabled and organized by Projekt DEAL.

\section{Declarations}

Conflict of interests The authors declare that there are no conflicts of interest.

Open Access This article is licensed under a Creative Commons Attribution 4.0 International License, which permits use, sharing, adaptation, distribution and reproduction in any medium or format, as long as you give appropriate credit to the original author(s) and the source, provide a link to the Creative Commons licence, and indicate if changes were made. The images or other third party material in this article are included in the article's Creative Commons licence, unless indicated otherwise in a credit line to the material. If material is not included in the article's Creative Commons licence and your intended use is not permitted by statutory regulation or exceeds the permitted use, you will need to obtain permission directly from the copyright holder. To view a copy of this licence, visit http://creativecommons.org/licenses/by/4.0/.

\section{References}

Abo-El-Enein S, a., Ali a. H, Talkhan FN, Abdel-Gawwad H a. (2013) Application of microbial biocementation to improve the physico-mechanical properties of cement mortar. HBRC J 9:36-40. https://doi.org/10.1016/j.hbrcj. 2012.10.004

Almeida M do C, Covas D, Garcia Beceiro PM (2015) Rehabilitation of sewers and operational practices
Amin MGM, Si Unek J, Laegdsmand M (2014) Agricultural Water Management Simulation of the redistribution and fate of contaminants from soil-injected animal slurry. Agric Water Manag 131:17-29. https://doi.org/10.1016/j. agwat.2013.09.002

Arnaouteli S, Bamford NC, Stanley-Wall NR, Kovács ÁT (2021) Bacillus subtilis biofilm formation and social interactions. Nat Rev Microbiol. https://doi.org/10.1038/ s41579-021-00540-9

Auguet O, Pijuan M, Batista J et al (2015a) Changes in microbial biofilm communities during colonization of sewer systems. Appl Environ Microbiol 81:7271-7280. https://doi.org/10. 1128/AEM.01538-15

Auguet O, Pijuan M, Guasch-Balcells H et al (2015b) Implications of downstream nitrate dosage in anaerobic sewers to control sulfide and methane emissions. Water Res 68:522-532. https://doi.org/10.1016/j.watres.2014.09.034

Augustyniak A, Cendrowski K, Nawrotek P et al (2016) Investigating the interaction between Streptomyces sp. and titania/silica nanospheres. Water Air Soil Pollut 230:1-13. https://doi.org/10.1007/s11270-016-2922-z

Augustyniak A, Grygorcewicz B, Nawrotek P (2018) Isolation of multidrug resistant coliforms and their bacteriophages from swine slurry. Turkish J Vet Anim Sci 42:319-325. https://doi.org/10.3906/vet-1710-102

Augustyniak A, Sikora P, Cendrowski K et al (2019) Challenges in studying the incorporation of nanomaterials to building materials on microbiological models. In: Fesenko O, Yatsenko L (eds) Nanophotonics, nanooptics, nanobiotechnology, and their applications. Springer, Cham, pp 285-303

Balasubramanian S, Aubin-Tam ME, Meyer AS (2019) 3D printing for the fabrication of biofilm-based functional living materials. ACS Synth Biol 8:1564-1567. https://doi. org/10.1021/acssynbio.9b00192

Batt AL, Bruce IB, Aga DS (2006) Evaluating the vulnerability of surface waters to antibiotic contamination from varying wastewater treatment plant discharges. Environ Pollut 142:295-302. https://doi.org/10.1016/J.ENVPOL.2005. 10.010

Bitton G (2014) Microbiological Aspects of Drinking Water Treatment.

Bose S, Vahabzadeh S, Bandyopadhyay A (2013) Bone tissue engineering using 3D printing. Mater Today 16:496-504

Burmølle M, Thomsen TR, Fazli M et al (2010) Biofilms in chronic infections: a matter of opportunity: monospecies biofilms in multispecies infections. FEMS Immunol Med Microbiol 59:324-336. https://doi.org/10.1111/j.1574695X.2010.00714.X

Cao J, Zhang L, Hong J et al (2019) Different ferric dosing strategies could result in different control mechanisms of sulfide and methane production in sediments of gravity sewers. Water Res 164:114914. https://doi.org/10.1016/j. watres.2019.114914

Cárcamo-Oyarce G, Lumjiaktase P, Kümmerli R, Eberl L (2015) Quorum sensing triggers the stochastic escape of individual cells from Pseudomonas putida biofilms. Nat Commun 6:5945. https://doi.org/10.1038/ncomms6945

Cheng L, House MW, Weiss WJ, Banks MK (2016) Monitoring sulfide-oxidizing biofilm activity on cement surfaces using 
non-invasive self-referencing microsensors. Water Res 89:321-329. https://doi.org/10.1016/j.watres.2015.11.066

Das T, Sehar S, Koop L et al (2014) Influence of calcium in extracellular DNA mediated bacterial aggregation and biofilm formation. PLoS ONE 9:91935. https://doi.org/10. 1371/journal.pone.0091935

de Feo G, Antoniou G, Fardin HF et al (2014) The historical development of sewers worldwide. Sustain 6:3936-3974. https://doi.org/10.3390/su6063936

De Kievit TR (2009) Quorum sensing in Pseudomonas aeruginosa biofilms. Environ Microbiol 11:279-288. https://doi. org/10.1111/j.1462-2920.2008.01792.x

De Sordi L, Lourenço M, Debarbieux L (2019) "I will survive": a tale of bacteriophage-bacteria coevolution in the gut. Gut Microbes 10:92-99. https://doi.org/10.1080/19490976. 2018.1474322

Despot D, Reinhold L, Augustyniak A, Barjenbruch M (2021) Dosing free nitrous acid as an alternative sulphide control technology for pressure sewers in Germany. Water (switzerland). https://doi.org/10.3390/w13081015

Favier L, Simion AI, Matei E et al (2016) Photocatalytic oxidation of a hazardous phenolic compound over Tio 2 In a batch system. Environ Eng Manag J 15:2016

Fischer MA, Ulbricht A, Neulinger SC et al (2019) Immediate effects of ammonia shock on transcription and composition of a biogas reactor microbiome. Front Microbiol 10:2064. https://doi.org/10.3389/fmicb.2019.02064

Flemming HC, Wingender J, Szewzyk U et al (2016) Biofilms: an emergent form of bacterial life. Nat Rev Microbiol 14:563-575. https://doi.org/10.1038/nrmicro.2016.94

Gaylarde CC, Morton LHG (1999) Deteriogenic biofilms on buildings and their control: a review. Biofouling 14:59-74. https://doi.org/10.1080/08927019909378397

Gloag ES, Turnbull L, Huang A et al (2013) Self-organization of bacterial biofilms is facilitated by extracellular DNA. Proc Natl Acad Sci U S A 110:11541-11546. https://doi.org/10. 1073/pnas.1218898110

Grygorcewicz B, Grudziński M, Wasak A et al (2017) Bacteriophage-mediated reduction of Salmonella Enteritidis in swine slurry. Appl Soil Ecol 119:179-182. https://doi.org/ 10.1016/j.apsoil.2017.06.020

Grygorcewicz B, Roszak M, Golec P et al (2020a) Antibiotics act with vb_abap_agc01 phage against acinetobacter baumannii in human heat-inactivated plasma blood and galleria mellonella models. Int J Mol Sci 21:1-14. https://doi. org/10.3390/ijms21124390

Grygorcewicz B, Wojciuk B, Roszak M et al (2020b) Environmental phage-based cocktail and antibiotic combination effects on acinetobacter baumannii biofilm in a human urine model. Microb Drug Resist 00:1-11. https://doi.org/ 10.1089/mdr.2020.0083

Guerrero LD, Pérez MV, Orellana E et al (2020) Long-run bacteria-phage coexistence dynamics under natural habitat conditions in an environmental biotechnology system. ISME J. https://doi.org/10.1038/s41396-020-00802-Z

Gutierrez O, Sudarjanto G, Ren G et al (2014) Assessment of pH shock as a method for controlling sulfide and methane formation in pressure main sewer systems. Water Res 48:569-578. https://doi.org/10.1016/j.watres.2013.10.021

Gutiérrez D, Vandenheuvel D, Martínez B et al (2015) Two Phages, phiIPLA-RODI and phiIPLA-C1C, Lyse Mono- and Dual-Species Staphylococcal Biofilms. Appl Environ Microbiol 81:3336-3348. https://doi.org/10.1128/AEM. 03560-14

Haile T, Nakhla G, Allouche E, Vaidya S (2010) Evaluation of the bactericidal characteristics of nano-copper oxide or functionalized zeolite coating for bio-corrosion control in concrete sewer pipes. Corros Sci 52:45-53. https://doi.org/ 10.1016/j.corsci.2009.08.046

Harbulakova VO, Estokova A, Stevulova N et al (2013) Current trends in investigation of concrete biodeterioration. Procedia Eng 65:346-351. https://doi.org/10.1016/j.proeng. 2013.09.053

Huang J, Liu S, Zhang C et al (2019) Programmable and printable Bacillus subtilis biofilms as engineered living materials. Nat Chem Biol 15:34-41. https://doi.org/10. 1038/s41589-018-0169-2

Hughes KA, Sutherland IW, Clark J, Jones MV (1998) Bacteriophage and associated polysaccharide depolymerases: Novel tools for study of bacterial biofilms. J Appl Microbiol 85:583-590. https://doi.org/10.1046/j.1365-2672. 1998.853541.x

Humphries J, Xiong L, Liu J et al (2017) Species-independent attraction to biofilms through electrical signaling. Cell 168:200-209.e12

Hvitved-Jacobsen T, Vollertsen J, Nielsen AH (2013) Sewer processes. Microbiological and chemical process engineering of sewer networks, seconds. CRC Press, Boca Raton

Jassim SAA, Limoges RG, El-Cheikh H (2016) Bacteriophage biocontrol in wastewater treatment. World J Microbiol Biotechnol 32:1-10. https://doi.org/10.1007/s11274-0162028-1

Jensen H, Biggs CA, Karunakaran E (2016) The importance of sewer biofilms. Wiley Interdiscip Rev Water 3:487-494. https://doi.org/10.1002/wat2.1144

Jiang G, Yuan Z (2013) Synergistic inactivation of anaerobic wastewater biofilm by free nitrous acid and hydrogen peroxide. J Hazard Mater 250-251:91-98. https://doi.org/ 10.1016/j.jhazmat.2013.01.047

Jiang G, Gutierrez O, Yuan Z (2011) The strong biocidal effect of free nitrous acid on anaerobic sewer biofilms. Water Res 45:3735-3743. https://doi.org/10.1016/j.watres.2011.04. 026

Jiang G, Keating A, Corrie S et al (2013a) Dosing free nitrous acid for sulfide control in sewers: results of field trials in Australia. Water Res 47:4331-4339. https://doi.org/10. 1016/j.watres.2013.05.024

Jiang G, Sharma KR, Yuan Z (2013b) Effects of nitrate dosing on methanogenic activity in a sulfide-producing sewer biofilm reactor. Water Res 47:1783-1792. https://doi.org/ 10.1016/j.watres.2012.12.036

Jiang G, Wightman E, Donose BC et al (2014) The role of iron in sulfide induced corrosion ofsewer concrete. Water Res 49:166-174. https://doi.org/10.1016/j.watres.2013.11.007

Jurczak-Kurek A, Gąsior T, Nejman-Faleńczyk B et al (2016) Biodiversity of bacteriophages: morphological and biological properties of a large group of phages isolated from urban sewage. Sci Rep 6:34338. https://doi.org/10.1038/ srep34338 
Kaempfer W, Berndt M (1999) Estimation of service life of concrete pipes in sewer networks. Durab Build Mater Components 8:36-45

Karatan E, Watnick P (2009) Signals, regulatory networks, and materials that build and break bacterial biofilms. Microbiol Mol Biol Rev 73:310-347. https://doi.org/10.1128/ MMBR.00041-08

Keren-Paz A, Brumfeld V, Oppenheimer-Shaanan Y, KolodkinGal I (2018) Micro-CT X-ray imaging exposes structured diffusion barriers within biofilms. NPJ Biofilms Microbiomes 4:2-5. https://doi.org/10.1038/s41522-018-0051-8

Kiilerich B, Brejnrod AD, Vollertsen J, Kiilerich P (2019) Variations in microbiome composition of sewer biofilms due to ferrous and ferric iron dosing. Cogent Environ Sci. https://doi.org/10.1080/23311843.2019.1595293

Kong L, Zhang B, Fang J (2017) Study on the applicability of bactericides to prevent concrete microbial corrosion. Constr Build Mater 149:1-8. https://doi.org/10.1016/j. conbuildmat.2017.05.108

Kracke F, Vassilev I, Krömer JO (2015) Microbial electron transport and energy conservation: the foundation for optimizing bioelectrochemical systems. Front Microbiol 6:575. https://doi.org/10.3389/fmicb.2015.00575

Kushkevych I, Vítězová M, Vítěz T, Bartoš M (2017) Production of biogas: relationship between methanogenic and sulfate-reducing microorganisms. Open Life Sci 12:82-91. https://doi.org/10.1515/biol-2017-0009

Łagód G, Sobczuk H, Suchorab Z, Widomski MK (2010) Biofilm in gravitational sewer system and its influence on wastewater biodegradation. Ecol Chem Eng A 17:1645-1654

Lax S, Cardona C, Zhao D et al (2019) Microbial and metabolic succession on common building materials under high humidity conditions. Nat Commun. https://doi.org/10. 1038/s41467-019-09764-z

Lee D, Yeon D, Prindle A, Liu J, Süel GM (2017) SnapShot: electrochemical communication in biofilms. Cell 214:e1

Lehman SM, Donlan RM (2015) Bacteriophage-mediated control of a two-species biofilm formed by microorganisms causing catheter-associated urinary tract infections in an in vitro urinary catheter model. Antimicrob Agents Chemother 59:1127-1137. https://doi.org/10.1128/AAC. 03786-14

Lemire J, Alhasawi A, Appanna VP et al (2017) Metabolic defence against oxidative stress: the road less travelled so far. J Appl Microbiol 123:798-809. https://doi.org/10. 1111/jam.13509

Li X, Kappler U, Jiang G, Bond PL (2017) The ecology of acidophilic microorganisms in the corroding concrete sewer environment. Front Microbiol 8:683. https://doi.org/ 10.3389/fmicb.2017.00683

Li X, Wu B, Chen H et al (2018) Recent developments in smart antibacterial surfaces to inhibit biofilm formation and bacterial infections. J Mater Chem B 6:4274-4292. https:// doi.org/10.1039/C8TB01245H

Lin W, Huang Z, Gao S et al (2021) Evaluating the stability of prescription drugs in municipal wastewater and sewers based on wastewater-based epidemiology. Sci Total Environ 754:142414. https://doi.org/10.1016/j.scitotenv. 2020.142414
Liu Y, Ni B-J, Ganigu R et al (2015a) Sulfide and methane production in sewer sediments. Water Res. https://doi.org/ 10.1016/j.watres.2014.12.019

Liu Y, Sharma KR, Ni B-J et al (2015b) Effects of nitrate dosing on sulfidogenic and methanogenic activities in sewer sediment. Water Res 74:155-165. https://doi.org/10.1016/j. watres.2015.02.017

Logan NA, Vos PD (2015) Bacillus. Bergey's Man Syst Archaea Bact. https://doi.org/10.1002/9781118960608. gbm00530

López-Moreno A, Sepúlveda-Sánchez JD, Mercedes Alonso Guzmán EM, Le Borgne S (2014) Calcium carbonate precipitation by heterotrophic bacteria isolated from biofilms formed on deteriorated ignimbrite stones: influence of calcium on EPS production and biofilm formation by these isolates. Biofouling 30:547-560. https://doi.org/10. 1080/08927014.2014.888715

Lors C, Hondjuila Miokono ED, Damidot D (2017) Interactions between Halothiobacillus neapolitanus and mortars: Comparison of the biodeterioration between Portland cement and calcium aluminate cement. Int Biodeterior Biodegrad 121:19-25. https://doi.org/10.1016/j.ibiod. 2017.03.010

Madsen HI, Hvitved-Jacobsen T, Vollertsen J (2006) Gas phase transport in gravity sewers-a methodology for determination of horizontal gas transport and ventilation. Water Environ Res 78:2203-2209. https://doi.org/10.2175/ $106143005 \times 82253$

Mattila S, Ruotsalainen P, Jalasvuori M (2015) On-demand isolation of bacteriophages against drug-resistant bacteria for personalized phage therapy. Front Microbiol 6:1271. https://doi.org/10.3389/fmicb.2015.01271

Maurer-Jones M, Gunsolus IL, Meyer BM et al (2013) Impact of $\mathrm{TiO} 2$ nanoparticles on growth, biofilm formation, and flavin secretion in Shewanella oneidensis. Anal Chem 85:5810-5818. https://doi.org/10.1021/ac400486u

Mccaughey LC, Josts I, Grinter R et al (2016) Discovery, characterization and in vivo activity of pyocin SD2, a protein antibiotic from Pseudomonas aeruginosa. Biochem J 473:2345-2358. https://doi.org/10.1042/BCJ20160470

McInerney MJ, Struchtemeyer CG, Sieber J et al (2008) Physiology, ecology, phylogeny, and genomics of microorganisms capable of syntrophic metabolism. Ann N Y Acad Sci 1125:58-72. https://doi.org/10.1196/annals.1419.005

Meaden S, Koskella B (2013) Exploring the risks of phage application in the environment. Front Microbiol 4:358. https://doi.org/10.3389/fmicb.2013.00358

Möhle RB, Langemann T, Haesner M et al (2007) Structure and shear strength of microbial biofilms as determined with confocal laser scanning microscopy and fluid dynamic gauging using a novel rotating disc biofilm reactor. Biotechnol Bioeng 98:747-755. https://doi.org/10.1002/ bit. 21448

Monnet V, Gardan R (2015) Quorum-sensing regulators in Gram-positive bacteria: "cherchez le peptide." Mol Microbiol 97:181-184. https://doi.org/10.1111/mmi. 13060

Montesinos E (2007) Antimicrobial peptides and plant disease control. FEMS Microbiol Lett 270:1-11. https://doi.org/ 10.1111/j.1574-6968.2007.00683.x 
Murima P, McKinney JD, Pethe K (2014) Targeting bacterial central metabolism for drug development. Chem Biol 21:1423-1432. https://doi.org/10.1016/J.CHEMBIOL. 2014.08.020

$\mathrm{Ng}$ PL, Kwan AKH (2015) Improving concrete durability for sewerage applications. In: Tse PW (ed) Professional practices and certification, lecture notes in mechanical engineering. Springer, Berlin, pp 1043-1053

Ngo TD, Kashani A, Imbalzano G et al (2018) Additive manufacturing (3D printing): a review of materials, methods, applications and challenges. Compos Part B Eng 143:172-196

Nielsen J (2017) Systems biology of metabolism. Annu Rev Biochem 86:245-275. https://doi.org/10.1146/annurevbiochem-061516-044757

Noeiaghaei T, Mukherjee A, Dhami N, Chae SR (2017) Biogenic deterioration of concrete and its mitigation technologies. Constr Build Mater 149:575-586. https://doi.org/ 10.1016/j.conbuildmat.2017.05.144

Okabe S, Odagiri M, Ito T, Satoh H (2007) Succession of sulfuroxidizing bacteria in the microbial community on corroding concrete in sewer systems. Appl Environ Microbiol 73:971-980. https://doi.org/10.1128/AEM.02054-06

Onesios-Barry KM, Berry D, Proescher JB et al (2014) Removal of pharmaceuticals and personal care products during water recycling: microbial community structure and effects of substrate concentration. Appl Environ Microbiol 80:2440-2450. https://doi.org/10.1128/AEM.03693-13

Ounnar A, Favier L, Bouzaza A et al (2016) Kinetic study of spiramycin removal from aqueous solution using. Kinet Catal 57:200-206. https://doi.org/10.1134/ S0023158416020087

Panagopoulos A, Haralambous KJ (2020a) Minimal liquid discharge (MLD) and zero liquid discharge (ZLD) strategies for wastewater management and resource recovery-analysis, challenges and prospects. J Environ Chem Eng 8:104418. https://doi.org/10.1016/j.jece.2020.104418

Panagopoulos A, Haralambous KJ (2020) Environmental impacts of desalination and brine treatment: challenges and mitigation measures. Mar Pollut Bull 161:111773

Panagopoulos A, Haralambous KJ, Loizidou M (2019) Desalination brine disposal methods and treatment technologies: a review. Sci Total Environ 693:133545

Pankratova G, Leech N, Gorton L, Hederstedt L (2018) Extracellular electron transfer by the gram-positive bacterium Enterococcus faecalis. Biochemistry 57:4597-4603. https://doi.org/10.1021/acs.biochem.8b00600

Papenfort K, Bassler BL (2016) Quorum sensing signal-response systems in gram-negative bacteria. Nat Rev Microbiol 14:576-588. https://doi.org/10.1038/nrmicro. 2016.89

Parande AK, Ramsamy PL, Ethirajan S et al (2006) Deterioration of reinforced concrete in sewer environments. Proc Inst Civ Eng Munic Eng 159:11-20. https://doi.org/10. 1680/muen.2006.159.1.11

Parasion S, Kwiatek M, Gryko R et al (2014) Bacteriophages as an alternative strategy for fighting biofilm development. Polish J Microbiol 63:137-145. https://doi.org/10.1111/ 1462-2920.12212

Piotrowska M, Dziewit L, Ostrowski R et al (2020) Molecular characterization and comparative genomics of IncQ-3 plasmids conferring resistance to various antibiotics isolated from a wastewater treatment plant in Warsaw (Poland). Antibiotics 9:613. https://doi.org/10.3390/ antibiotics9090613

Ren Y, Wang C, Chen Z et al (2018) Emergent heterogeneous micro-environments in biofilms: substratum surface heterogeneity and bacterial adhesion force-sensing. FEMS Microbiol Rev 42:259-272. https://doi.org/10.1093/ femsre/fuy001/4794942

Ribeiro KVG, Ribeiro C, Dias RS et al (2018) Bacteriophage isolated from sewage eliminates and prevents the establishment of escherichia coli biofilm. Adv Pharm Bull 8:85-95. https://doi.org/10.15171/apb.2018.011

Romero D, Traxler MF, López D, Kolter R (2011) Antibiotics as signal molecules. Chem Rev 111:5492-5505. https://doi. org/10.1021/cr2000509

Saeidi N, Wong CK, Lo T-M et al (2011) Engineering microbes to sense and eradicate Pseudomonas aeruginosa, a human pathogen. Mol Syst Biol 7:521. https://doi.org/10.1038/ msb.2011.55

Salmond GPC, Fineran PC (2015) A century of the phage: past, present and future. Nat Rev Microbiol 13:777-786. https:// doi.org/10.1038/nrmicro3564

Sarjit A, Mei Tan S, Dykes GA, (2015) Surface modification of materials to encourage beneficial biofilm formation. AIMS Bioeng 2:404-422. https://doi.org/10.3934/bioeng.2015.4. 404

Scanlan PD (2017) Bacteria-bacteriophage co-evolution in the human gut: implications for microbial diversity and functionality. Trends Microbiol 25:614-623

Schmieden DT, Basalo Vázquez SJ, Sangüesa H et al (2018) Printing of patterned, engineered E. coli biofilms with a low-cost 3D printer. ACS Synth Biol 7:1328-1337. https:// doi.org/10.1021/acssynbio.7b00424

Shimizu K (2013) Metabolic regulation of a bacterial cell system with emphasis on escherichia coli metabolism. ISRN Biochem 2013:1-47. https://doi.org/10.1155/2013/645983

Shirakawa MA, John VM, De Belie N et al (2015) Susceptibility of biocalcite-modified fiber cement to biodeterioration. Int Biodeterior Biodegrad 103:215-220. https://doi.org/10. 1016/j.ibiod.2015.04.003

Sikora P, Augustyniak A (2017) Utilization of Nanomaterials for reduction of microbiologically induced deterioration (mid) of cement-based composites. In: Çınar Ö (ed) III international conference on sustainable development. Book of proceedings. pp 33-36

Sikora P, Augustyniak A, Cendrowski K et al (2018) Antimicrobial activity of $\mathrm{Al} 2 \mathrm{O} 3, \mathrm{CuO}, \mathrm{Fe} 3 \mathrm{O} 4$, and $\mathrm{ZnO}$ nanoparticles in scope of their further application in cement-based building materials. Nanomaterials 8:212. https://doi.org/10.3390/nano8040212

Silvestre J, Silvestre N, de Brito J (2016) Review on concrete nanotechnology. Eur J Environ Civ Eng 20:455-485. https://doi.org/10.1080/19648189.2015.1042070

Singh S, Singh SK, Chowdhury I, Singh R (2017) Understanding the mechanism of bacterial biofilms resistance to antimicrobial agents. Open Microbiol J 11:53-62. https:// doi.org/10.2174/1874285801711010053

Song B, Leff LG (2006) Influence of magnesium ions on biofilm formation by Pseudomonas fluorescens. Microbiol Res 
161:355-361. https://doi.org/10.1016/J.MICRES.2006.01. 004

(2015) Sporosarcina. In: Trujillo ME, Dedysh S, DeVos P, Hedlund B, Kämpfer P, Rainey FA, Whitman WB (eds) Bergey's manual of systematics of archaea and bacteria. https://doi.org/10.1002/9781118960608.gbm00563

Sun X, Jiang G, Bond PL et al (2015) A novel and simple treatment for control of sulfide induced sewer concrete corrosion using free nitrous acid. Water Res 70:279-287. https://doi.org/10.1016/j.watres.2014.12.020

Suzzi G, Tresse O, Perpetuini G et al (2018) Enhanced biofilm formation by ferrous and ferric iron through oxidative stress in Campylobacter jejuni. Front Microbiol. https:// doi.org/10.3389/fmicb.2018.01204

Sydney R, Esfandi E, Surapaneni S (1996) Control concrete sewer corrosion via the crown spray process. Water Environ Res 68:338-347

Ungureanu CP, Bahrim G, Popa Ungureanu C et al (2016) Screening of soil bacteria as potential agents for drugs biodegradation: a case study with clofibric acid. J Chem Technol Biotechnol 91:1646-1653. https://doi.org/10. 1002/jctb.4935

Van Tittelboom K, De Belie N, De Muynck W, Verstraete W (2010) Use of bacteria to repair cracks in concrete. Cem Concr Res 40:157-166. https://doi.org/10.1016/j. cemconres.2009.08.025

Voegel C, Giroudon M, Bertron A et al (2019) Cementitious materials in biogas systems: biodeterioration mechanisms and kinetics in CEM I and CAC based materials. Cem Concr Res 124:105815. https://doi.org/10.1016/j. cemconres.2019.105815

Vollertsen J, Nielsen AH, Jensen HS et al (2008) Corrosion of concrete sewers - the kinetics of hydrogen sulfide oxidation. Sci Total Environ 394:162-170. https://doi.org/10. 1016/J.SCITOTENV.2008.01.028

Vupputuri S, Fathepure BZ, Wilber GG et al (2015) Isolation of a sulfur-oxidizing Streptomyces sp. from deteriorating bridge structures and its role in concrete deterioration. Int Biodeterior Biodegradation 97:128-134. https://doi.org/ 10.1016/j.ibiod.2014.11.002

Wang X, Jiang M, Zhou Z et al (2017) 3D printing of polymer matrix composites: a review and prospective. Compos Part B Eng 110:442-458
Wei S, Jiang Z, Liu H et al (2013) Microbiologically induced deterioration of concrete-a review. Brazilian J Microbiol 44:1001-1007

Werb M, García CF, Bach NC et al (2017) Surface topology affects wetting behavior of Bacillus subtilis bio films. npj Biofilms Microbiomes. https://doi.org/10.1038/s41522017-0018-1

Westerholm M, Schnürer A (2018) Microbial responses to different operating practices for biogas production systems. In: Anaerobic digestion. pp 1-36

WHO (2014) ANTIMICROBIAL resistance global report on surveillance. World Health Organisation, Geneva

Wong L, Nehdi M (2018) Critical analysis of international precast concrete pipe standards. Infrastructures 3:18. https://doi.org/10.3390/infrastructures3030018

Worthington RJ, Richards JJ, Melander C (2012) Small molecule control of bacterial biofilms. Org Biomol Chem 10:7457-7474. https://doi.org/10.1039/c2ob25835h

Wu L, Hu C, Liu WV (2018) The sustainability of concrete in sewer tunnel-a narrative review of acid corrosion in the city of Edmonton, Canada. Sustain. doi: https://doi.org/10. 3390/su10020517

Yang Y, Ji T, Lin X et al (2018) Biogenic sulfuric acid corrosion resistance of new artificial reef concrete. Constr Build Mater 158:33-41

Yuan H, Dangla P, Chatellier P, Chaussadent T (2015) Degradation modeling of concrete submitted to biogenic acid attack. Cem Concr Res 70:29-38. https://doi.org/10.1016/ j.cemconres.2015.01.002

Zhang M, Liu X, Li Y et al (2017) Microbial community and metabolic pathway succession driven by changed nutrient inputs in tailings: effects of different nutrients on tailing remediation. Sci Rep 7:474. https://doi.org/10.1038/ s41598-017-00580-3

Zhao JQ, Kuraoka S, Gu THW et al (1988) Durability and performance of gravity pipes: a state-of-the-art literature review. National Research Council of Canada, Ottawa

Publisher's Note Springer Nature remains neutral with regard to jurisdictional claims in published maps and institutional affiliations. 